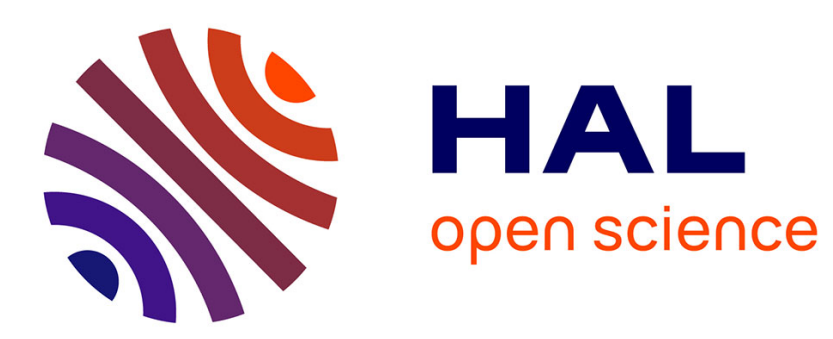

\title{
Should transdermal rather than oral estrogens be used in menopausal hormone therapy?: a review
}

\author{
Agnès Fournier
}

\section{To cite this version:}

Agnès Fournier. Should transdermal rather than oral estrogens be used in menopausal hormone therapy?: a review. Menopause international., 2010, 16 (1), pp.23-32. 10.1258/mi.2010.010009 . inserm-01320273

\section{HAL Id: inserm-01320273 https://www.hal.inserm.fr/inserm-01320273}

Submitted on 23 May 2016

HAL is a multi-disciplinary open access archive for the deposit and dissemination of scientific research documents, whether they are published or not. The documents may come from teaching and research institutions in France or abroad, or from public or private research centers.
L'archive ouverte pluridisciplinaire HAL, est destinée au dépôt et à la diffusion de documents scientifiques de niveau recherche, publiés ou non, émanant des établissements d'enseignement et de recherche français ou étrangers, des laboratoires publics ou privés. 
SHOULD TRANSDERMAL RATHER THAN ORAL ESTROGENS BE USED IN MENOPAUSAL HORMONE THERAPY? A REVIEW

Agnès Fournier

Nutrition, Hormones and Women's Health, Centre for Research in Epidemiology and Population Health (CESP), U1018, Inserm (Institut National de la Santé et de la Recherche Médicale), Institut Gustave Roussy, F-94805 Villejuif, France Université Paris Sud 11, UMRS 1018, F-94805 Villejuif, France

\section{Contact}

Agnès Fournier, Inserm U1018, Institut Gustave Roussy, 39 rue Camille Desmoulins, F-94805 Villejuif, France

Tel +33142115092

Fax +33142114000

E-mail : fournier@igr.fr

Keywords

Epidemiology, estrogens, menopausal hormone therapy, oral, transdermal 


\section{ABSTRACT}

The current evaluation of the benefit/risk ratio associated with menopausal hormone therapy (MHT) use is largely based on clinical trials which investigated the effects of oral treatments. Would MHT with transdermal estrogens be associated with a more favourable benefit/risk ratio? We reviewed the available epidemiologic evidence on that question. Epidemiologic studies were considered if they provided risk estimates of conditions which carry an important weight among menopausal women, and for which epidemiologic evidence of a possible link with MHT use is convincing: cardiovascular diseases, breast cancer, diabetes, colorectal cancer and hip fracture. We did not include studies with only surrogate measures. We found that the available information on the potential impact of the route of administration of MHT on the risk of our selected outcomes is limited. To date, epidemiologic data suggest that it has no impact on the risk of breast cancer and hip fracture. Results on the risk of coronary heart disease and colorectal cancer are inconsistent. Studies on stroke and diabetes risk are too few to allow meaningful conclusions. There is a suggestion that transdermal MHT may be less deleterious than oral MHT regarding venous thromboembolism which needs to be confirmed. The issue of the route of administration of MHT should remain an active area of research as part of an attempt to identify treatment modalities that would have the least potential for exerting adverse effects. 


\section{INTRODUCTION}

Cardiovascular safety concerns demonstrated by the Women's Health Initiative (WHI) randomized controlled trial ${ }^{1}$ together with the WHI and the Million Women Study reports of an increased breast cancer risk among estrogenprogestagen menopausal hormone therapy (MHT) users ${ }^{2 ; 3}$ led the European Medicines Agency to restrict indications of MHT to the treatment of climacteric symptoms: it considered that, otherwise, risks outweigh benefits. ${ }^{4}$ The American WHI trial evaluated oral conjugated equine estrogens, used alone or associated continuously with oral medroxyprogesterone acetate, but many other types of MHT are used around the world: estrogens can also be administered through the skin, other estrogenic and progestagenic molecules can be used, with different doses and different numbers of days of use per month. One must of course consider that the risks observed in the WHI also apply to other types of MHT until the contrary is demonstrated. Meanwhile, one should aim at identifying the safest modalities of use of MHT.

The present review will focus on the route of administration of the estrogenic component of MHT: may transdermal MHT be associated with a more favourable risk/benefit ratio than oral MHT? Because of the often complex interplay of biologic mechanisms at work when MHT is administered, we generally need epidemiologic studies with clinical outcomes to appreciate the net effect of MHT on the risk of a given disease. We therefore performed a review of the epidemiologic evidence available to date on the impact of the route of administration of MHT on the risk of selected conditions. 


\section{METHODS}

We chose to focus on conditions which carry an important weight among menopausal women, and for which epidemiologic evidence of a possible link with MHT use is convincing. Of these, ischaemic heart disease and cerebrovascular disease constitute a considerable burden among women aged 45 years or more in the established market economies, followed by breast cancer and diabetes mellitus, and then by colorectal cancer and hip fracture. ${ }^{5 ; 6}$ We also considered venous thromboembolism together with ischaemic heart disease and cerebrovascular disease in a "cardiovascular disease" category because pulmonary embolism is a potentially fatal condition for which a link with MHT use is demonstrated.

We included epidemiologic studies (clinical trials, case-control and cohort studies) when they provided risk estimates of the considered condition. We did not include studies with only surrogate measures (such as bone mineral density) as outcomes, because variations in individual intermediate biomarkers may not directly translate into clinically relevant variations in the risk of the condition considered. Sample size, main characteristics of included women, risk estimates, 95\% confidence intervals $[\mathrm{Cl}]$ and results of the tests for homogeneity between estimates associated with oral and transdermal MHT are given when available.

In the following, the term "MHT" is used when estrogen-alone and estrogenprogestagen therapy are not distinguished; "E-MHT" designates estrogen-alone therapy; "EP-MHT" designates estrogen-progestagen therapy; "transdermal” MHT designates transdermal (i.e. in the form of gel or patch) estrogen, associated or not with a progestagen (whatever the route of administration of the progestagen). 
For each condition, we begin with a brief reminder of what is known about its relation with MHT use and we then examine the epidemiological evidence available regarding the impact of the route of administration of MHT.

\section{RESULTS}

\section{CARDIOVASCULAR DISEASE}

Ischaemic heart disease

In the 1990s, based on consistent evidence from observational studies, MHT was thought to reduce the risk of coronary heart disease (CHD) by $30 \%$ or more. ${ }^{7}$ However, this was not confirmed in subsequent randomized controlled trials which even demonstrated an early harm of EP-MHT. ${ }^{8-11}$ Potential explanations for these contradictory findings included methodological weaknesses that affect observational studies, such as their inability to properly identify events that occur soon after MHT initiation (in the case of cohort studies) and to properly eliminate confounding by socio-economic, health or behavioural parameters. ${ }^{12 ; 13}$ As participants in randomized trials were in average several years older at treatment initiation compared with those included in observational studies, it was also postulated that $\mathrm{CHD}$ risk might be lessened when $\mathrm{MHT}$ is started soon after menopause rather than later. ${ }^{14}$ This "timing hypothesis" is however currently not confirmed. ${ }^{15}$ The effect of MHT on CHD risk therefore remains unclear.

Randomized trials which evaluated transdermal MHT provided no evidence that it is associated with a beneficial effect on CHD risk or that it differs from oral MHT concerning this risk. ${ }^{16}$ Results from observational studies comparing oral and 
transdermal MHT are inconsistent (Table 1). Some found similar risk reductions associated with both oral and transdermal MHT, ${ }^{17 ; 18}$ one case-control study showed transdermal MHT to be associated with a significantly elevated CHD risk compared with oral $\mathrm{MHT}^{19}$ whereas two record-linkage cohort studies suggested the contrary, ${ }^{20 ; 21}$ and another study suggested increases in risk for both oral and transdermal MHT. ${ }^{22}$ Of note, only one of these studies excluded premenopausal women ${ }^{18}$ and only Løkkegaard et al. ${ }^{21}$ compared oral and transdermal MHT without progestagen.

The effect of MHT on CHD risk is therefore ambiguous, and there is currently no consistent evidence for an effect of the route of estrogen administration.

\section{Cerebrovascular disease}

Evidence from clinical trials shows MHT to be associated with a significant $30 \%$ increase in risk of total stroke, ${ }^{16 ; 23}$ with no difference between E-MHT and EPMHT. ${ }^{16}$ It is further suggested that, among subjects who have stroke, those in the MHT groups have a worse outcome, ${ }^{16 ; 23}$ and that the deleterious effect of MHT is limited to ischaemic stroke. ${ }^{23} \mathrm{~A}$ meta-analysis of nine cohort studies published in 2002 also points toward a significant increase in ischaemic but not haemorrhagic stroke with MHT ever-use compared with never-use. ${ }^{24}$ Of the largest recent observational studies evaluating the risk of stroke in relation to MHT use, three are concordant with these conclusions, ${ }^{25-27}$ whereas both Lemaitre et al. ${ }^{29}$ and Prentice et al. ${ }^{28}$ found no evidence of an elevation in the risk of stroke with MHT use.

The possibility of a differential effect between transdermal and oral MHT regarding stroke risk has been rarely investigated. In the meta-analysis of trials performed by Sare et al., ${ }^{16}$ subgroup analyses showed no difference in 
cerebrovascular events for oral versus transdermal administration (but the number of trials using transdermal administration was small). Only two observational investigations compared transdermal and oral MHT in this regard. The first one is a nested case-control study using data from the UK General Practice Research Database, which included 920 women 50-69 years old with a diagnosis of first ischaemic stroke, haemorrhagic stroke or transient ischaemic attack and 10,000 controls. ${ }^{25}$ Regarding transient ischaemic attacks, and compared with MHT neveruse, there was a suggestion of a greater risk associated with oral MHT (multivariable-adjusted odds-ratio [OR] 1.47; 95\% Cl 1.09-1.97) than with transdermal MHT (multivariable-adjusted OR $0.86,95 \% \mathrm{Cl} 0.43-1.73$ ) but the $\mathrm{Cls}$ largely overlap, which is compatible with no difference between the two types of MHT. The small number of users of transdermal preparations precluded a similar assessment for ischaemic and haemorrhagic stroke risks, which were nonsignificantly slightly increased with current MHT use. The second study investigating oral and transdermal MHT concerning the risk of stroke is an Italian record-linkage study which examined the effect of the persistence with MHT. ${ }^{20}$ It included 76,875 women aged 45-65 years who received at least one MHT prescription during 1998-2000, of whom 298 experienced hospitalization for cerebrovascular disease. Compared with women who took oral MHT for $\leq 6$ months, those exposed for 2-3 years and $>3$ years showed multivariable-adjusted HazardRatios (HRs) of $0.73(95 \% \mathrm{Cl} 0.18-2.93)$ and 0.54 (95\% $\mathrm{Cl} 0.08-3.86)$, respectively; compared with women who took transdermal MHT (mainly patches) for $<6$ months, those exposed for 2-3 years and $>3$ years showed multivariable-adjusted HRs of $0.50(95 \% \mathrm{Cl} 0.29-0.87)$ and $0.39(95 \% \mathrm{Cl} 0.18-0.82)$, respectively. 
It can be concluded that the very few data exploring the effect of the route of administration of MHT on the risk of stroke do not suggest any strong effect of that parameter.

\section{Venous thromboembolism}

Evidence from both clinical trials and observational studies is consistent in indicating current use of MHT to be associated with a two- or three-fold increased risk of venous thromboembolism (including deep vein thrombosis and pulmonary embolism), with the highest risks occurring in the first year of use. ${ }^{16 ; 24 ; 30}$ Trials further suggest that the risk is less elevated with the use of E-MHT rather than EPMHT. ${ }^{16}$

Studies evaluating the risk of venous thromboembolism with transdermal MHT are not numerous. Sare et $a l .{ }^{16}$ noted no significant difference between oral and transdermal MHT in their meta-analysis of clinical trials, but the number of trials using transdermal administration was small. The earliest observational studies evaluating the risk of venous thromboembolism with transdermal MHT included very few cases among transdermal MHT users (Table 2). They found no significant difference between oral and transdermal MHT. ${ }^{31-33}$ In an Italian population-based record-linkage study including 171 women aged 45-79 years with an idiopathic venous thromboembolism episode and 10,000 controls, $79 \%$ of exposure was with transdermal EP-MHT; the multivariable-adjusted OR associated with MHT current-use was 2.3 (95\% Cl, 1.0-5.3; six cases among MHT users) compared with MHT never-use. ${ }^{34}$ The most recent observational studies comparing the risk of venous thromboembolism associated with oral and transdermal MHT have been performed in France, where use of transdermal estrogens is 
predominant. ${ }^{35 ; 36}$ Both found oral but not transdermal estrogen associated with a significant increase in venous thromboembolism risk. In the cohort study, the HRs associated with oral and transdermal estrogens differed significantly. ${ }^{36}$

In conclusion, there is a recent suggestion from observational studies that transdermal MHT may be less deleterious than oral MHT regarding the risk of venous thromboembolism. This finding needs to be confirmed in future studies, which should carefully: (i) disentangle the effects of route of administration and progestagen molecule, since the French studies suggested that different progestagens may have different effects on the venous thromboembolism risk ${ }^{35 ; 36}$; (ii) limit incomplete capture of early events (which is likely to have happened in the French prospective cohort study) since the highest risks are seen in the first year of use ${ }^{13}$; and (iii) compare oral and transdermal MHT within homogeneous strata of time since treatment initiation, for the same reason.

\section{BREAST CANCER}

The relation between MHT use and breast cancer risk has been investigated in many epidemiological studies, whose results have led to the conclusion that EPMHT is carcinogenic to the human breast. ${ }^{37}$ Evidence comes from clinical trials and observational studies which suggest $\mathrm{a} \approx 30-70 \%$ increase in risk with EP-MHT current use, ${ }^{38 ; 39}$ which would disappear a few years after treatment discontinuation. ${ }^{39 ; 40}$ MHT use as a breast cancer risk factor gained additional support from the concomitant reductions in breast cancer incidence and in the use of MHT recently observed in several countries. ${ }^{41}$ EP-MHT use has been found associated with a greater breast cancer risk than E-MHT, but whether the latter is associated with an increase in breast cancer risk compared with MHT never-use is still the subject of 
intense debate: use of estrogen-alone was associated with a decreased risk in the WHI trial ${ }^{42}$ but not in observational studies. ${ }^{38 ; 39}$

The impact of the route of administration of MHT on breast cancer risk began to be investigated lately (Table 3). To our knowledge, the UK Million Women Study investigators are the first to have done so, and their prospective cohort is the largest on the question. ${ }^{3}$ In this study, there was no significant difference between HRs associated with oral and transdermal E-MHT. Then, in Finland, Lyytinen et al. ${ }^{43}$ reached the same conclusion after having compared oral and transdermal E-MHT with similar doses and durations of use. In another study focusing on EP-MHT, they found that oral and transdermal EP-MHT showed similar trends in the risk elevation. ${ }^{44}$ The same authors were then able to compare oral and transdermal EPMHT for a given progestagen (i.e. norethisterone acetate) in a further case-control study. ${ }^{45}$ Again, they found no large difference between oral and transdermal EPMHT regarding the risk of breast cancer. In the French E3N cohort study, no significant difference was found between the effect estimates associated wit oral and transdermal MHT, for a given associated progestagen. ${ }^{46 ; 47}$ In a study based on the UK General Practice Research Database, Opatrny et al. ${ }^{48}$ found that oral but not transdermal MHT ever-use was associated with a significant increase in risk; however, Cls associated with oral and transdermal MHT overlap, which is compatible with no difference in risk estimates. Finally, only one study found a significant difference in the estimated effects of oral and transdermal MHT. That cohort study investigated the effect of the persistence with MHT and included only women who had received at least one MHT prescription during 1998-2000. ${ }^{49}$ Compared with women who took oral MHT for $<6$ months, those exposed for $>2$ years showed an age-adjusted $\mathrm{HR}$ of $2.14(95 \% \mathrm{Cl} 1.43-3.21)$ whereas, compared 
with women who took transdermal MHT (mainly patches) for $<6$ months, those exposed for $>2$ years showed age-adjusted HR of $1.27(95 \% \mathrm{Cl} 1.07-1.51)$.

The best observational evidence regarding the impact of the route of administration of MHT on the risk of breast cancer comes from studies that have evaluated E-MHT, since there is serious suggestion that the risk of breast cancer is also influenced by the progestagen component of EP-MHT and its modalities of use.$^{50}$ The best observational evidence to date therefore suggests that there is no differential effect of oral and transdermal MHT on the risk of breast cancer.

\section{DIABETES}

Use of MHT is likely to decrease the risk of type 2 diabetes, as suggested by a meta-analysis of clinical trials evaluating oral MHT, which showed a $30 \%$ reduction in risk for women in the MHT groups. ${ }^{51}$ Observational studies on the relation between MHT use and risk of diabetes are scarce. Two prospective observational studies both including $\approx 1200$ cases of type 2 diabetes found the risk to be significantly reduced among MHT users compared with never-users. ${ }^{52 ; 53}$ Among prospective studies of much more limited size, two found no significant association between MHT use and risk of diabetes, ${ }^{54 ; 55}$ whereas a third one found a significant decrease in risk among MHT users compared with never-users. ${ }^{56}$

The latter study evaluated exclusively transdermal EP-MHT but is based on only six cases of diabetes among users. To our knowledge, the only study that directly compared oral and transdermal MHT is the French E3N prospective cohort, which included 63,624 postmenopausal women among whom 1220 new-onset diabetes cases were identified. ${ }^{53}$ Use of oral MHT was associated with a significantly greater decrease in diabetes risk than use of transdermal MHT 
(compared with MHT never-use, multivariable-adjusted $\mathrm{HR} 0.68,95 \% \mathrm{Cl}$ 0.55-0.85, 125 cases among oral MHT users; HR 0.87, 95\% Cl 0.75-1.00, 425 cases among transdermal MHT users; $P$ for homogeneity between these two HRs 0.028 ). However, the authors explain that some progestagens were preferentially combined with either oral or transdermal estrogens, which makes possible that the difference between the two HRs in fact reflected differences between progestagens. They did not observe significant differences in oral and transdermal effect estimates within homogeneous categories of progestagen, but the number of cases may have been too low.

In conclusion, the single observational study evaluating the impact of the route of administration of MHT on the risk of diabetes provides a weak suggestion that oral MHT may have a more marked protective effect than transdermal MHT.

\section{COLORECTAL CANCER}

Epidemiological evidence for a link between MHT use and colorectal cancer risk is equivocal, but in aggregate, it points toward a possible protective effect. A meta-analysis of observational studies indicates a $\approx 20 \%$ reduction in colorectal cancer risk with MHT ever-use, with much of the apparent reduction limited to recent use. ${ }^{57}$ These results mainly pertain to E-MHT, since the studies included in the meta-analysis were mostly performed before use of EP-MHT became widespread. The largest recent observational studies generally suggest a similar protective effect of EP-MHT. ${ }^{58-60}$ However, one case-control study found the risk reduction to be limited to users of EP-MHT, ${ }^{61}$ whereas one cohort study concluded the contrary ${ }^{62}$; another large cohort study even found no link between MHT use and colorectal cancer risk. ${ }^{63}$ In the WHI trials, E-MHT was not significantly associated 
with colorectal cancer risk, ${ }^{64}$ while EP-MHT conferred a statistically significant reduction in risk. ${ }^{65}$ The latter reduced incidence was however offset by the finding that colorectal cancers tended to be more advanced, with more likelihood of lymphatic or metastatic involvement. Although based on a low number of cases, which limits interpretation, the WHI results therefore cast doubts on the colorectal cancer benefit with MHT.

Whether this possible protective effect of MHT on colorectal cancer risk varies according to its route of administration has been investigated in five observational studies (Table 4). Three found both oral and transdermal MHT associated with decreases in colorectal cancer risk ${ }^{49 ; 66 ; 67}$; there was no evidence of a difference between the risk estimates associated with oral and transdermal MHT in two of them, ${ }^{49 ; 67}$ while Csizmadi et al ${ }^{66}$ found transdermal MHT associated with a significantly greater decrease in risk than oral MHT, but only when the analyses were restricted to women with exclusive use of one route of administration. In another observational study, ever-use of MHT via oral or transdermal routes of administration both showed no significant association with colon cancer. ${ }^{68}$ Finally, a population-based case-control study found oral but not transdermal MHT associated with a significant decrease in risk, but the difference between the two routes of administration was not significant. ${ }^{60 ; 67}$

Results of these five observational studies are not consistent and generally based on low number of cases among transdermal MHT users (no more than 26 cases, when the information was available). Taken together, they do not provide convincing evidence of an impact of the route of administration on the still debated colorectal cancer benefit of MHT. 


\section{HIP FRACTURE}

Evidence from clinical trials concerning the relation between MHT use and the risk of hip fracture derives mainly from the WHI: both WHI trials (E-MHT and EP-MHT) found a statistically significant $30-40 \%$ reduction in risk for women in the treated groups. ${ }^{69 ; 70}$ In the Heart and Estrogen/progestin Replacement Study (HERS) trial however, no protective effect of MHT was observed and the unblinded extension of this trial even showed a statistically significant increased risk in the MHT group, but the authors attributed this finding to chance. ${ }^{71}$ Before the release of the HERS and WHI results, a meta-analysis of randomized trials showed MHT to be associated with a $40 \%$ significant decrease in the risk of hip/wrist fracture. ${ }^{72}$ Evidence from observational studies points toward the same direction: pooled data from three cohort studies indicate a HR of hip fracture of $0.64(95 \% \mathrm{Cl} 0.32-1.04)$ for current MHT use versus never-use. ${ }^{24}$ More recent observational studies also support such a protective effect. ${ }^{73-75}$

Investigations of a possible differential effect of oral and transdermal MHT on the risk of fracture, in particular hip fracture, are scarce. One of these is a Swedish population-based case-control study which included 1327 women aged 5081 years with hip fracture and 3262 controls. ${ }^{76}$ Compared with MHT never-use, oral E-MHT ever-use was associated with an OR of $0.63(95 \% \mathrm{Cl} 0.45-0.88 ; 59$ cases among MHT users) and patches of E-MHT with an OR of $0.73(95 \% \mathrm{Cl} 0.38-1.40 ; 15$ cases among MHT users); oral EP-MHT was associated with an OR of $0.46(95 \% \mathrm{Cl}$ 0.32-0.67; 55 cases among MHT users) and patches of EP-MHT with an OR of 0.49 (95\% Cl 0.24-1.00; 12 cases among MHT users). The prospective Million Women Study, which included 138,737 postmenopausal women from the UK aged 50-69 years of whom 5197 reported one or more fractures, found similar results. ${ }^{73}$ 
Compared with MHT never-users, multivariable-adjusted HRs of fracture were 0.60 (95\% $\mathrm{Cl}$ 0.53-0.68; 290 cases among MHT users) for current use of oral E-MHT and 0.75 (95\% $\mathrm{Cl} 0.65-0.86 ; 197$ cases among MHT users) for current use of transdermal E-MHT. Finally, in a Danish record-linkage case-control study which included 64,548 women with fracture and 193,641 controls, multivariable-adjusted ORs were very close for oral and transdermal MHT in the age groups $50-59$ years and $\geq 60$ years (where women were most likely postmenopausal). ${ }^{74}$

The epidemiologic evidence to date therefore suggests that oral and transdermal MHT would have a similar protective effect on the risk of hip fracture.

\section{CONCLUSION}

Available information on the potential impact of the route of administration of MHT on the risk of clinically important outcomes is limited. To date, epidemiological data suggest that it has no impact on the risk of breast cancer and hip fracture. Results on the risk of CHD and colorectal cancer are inconsistent. Studies on stroke and diabetes risk are too few to allow meaningful conclusions. There is a suggestion that transdermal MHT may be less deleterious than oral MHT regarding venous thromboembolism which needs to be confirmed.

The issue of the route of administration of MHT should therefore remain an active area of research as part of an attempt to identify treatment modalities that would have the least potential for exerting adverse effects. To date, limited statistical power and a lack of comprehensive data collection have hindered the ability of most studies to simultaneously take into account several aspects of MHT use, and future studies should now be designed so as to be able to disentangle the 
effects of various MHT parameters: molecules, doses, regimens, and route of administration. 
Table 1. Risk of coronary heart disease - Results of observational studies comparing oral and transdermal MHT

\begin{tabular}{|c|c|c|c|c|}
\hline $\begin{array}{l}\text { First Author and } \\
\text { publication year }\end{array}$ & $\begin{array}{c}\text { Country and characteristics of } \\
\text { participants }\end{array}$ & Design and size of the study & Risk estimates ( $95 \% \mathrm{Cl}$; No of exposed cases) & Other \\
\hline \multirow{3}{*}{$\begin{array}{l}\text { Varas-Lorenzo } \\
(2000)^{17}\end{array}$} & \multirow{3}{*}{$\begin{array}{l}\text { United Kingdom, women aged } \\
50-74 \text { years }\end{array}$} & \multirow{2}{*}{$\begin{array}{l}\text { Population-based case-control } \\
\text { study using the General } \\
\text { Practice Research Database }\end{array}$} & ORs for recent use versus MHT never-use: & ORs are multivariable-adjusted \\
\hline & & & Oral MHT: 0.66 (0.50-0.88; 63 cases) & \multirow{2}{*}{$\begin{array}{l}\text { The effect of oral and transdermal } \mathrm{MHT} \\
\text { has been assessed in recent users with } \\
\text { duration }>1 \text { year }\end{array}$} \\
\hline & & $\begin{array}{l}1013 \text { women with myocardial } \\
\text { infarction and } 5000 \text { controls }\end{array}$ & Transdermal MHT: 0.75 (0.47-1.21; 22 cases) & \\
\hline \multirow[t]{6}{*}{ Chilvers $(2003)^{19}$} & \multirow{6}{*}{$\begin{array}{l}\text { United Kingdom, women aged } \\
35-65 \text { years }\end{array}$} & Case-control study & ORs of non-fatal events for ever-use versus MHT never-use: & \multirow{2}{*}{$\begin{array}{l}\text { ORs are multivariable-adjusted for non } \\
\text { fatal events, and only age-adjusted for } \\
\text { fatal events. }\end{array}$} \\
\hline & & \multirow{2}{*}{$\begin{array}{l}559 \text { women with non fatal } \\
\text { myocardial infarction and } 1118 \\
\text { controls }\end{array}$} & Oral MHT: 0.68 (0.49-0.95; 139 cases $)$ & \\
\hline & & & Transdermal MHT: 1.70 (0.58-4.98; 9 cases) & \multirow{4}{*}{$\begin{array}{l}\text { ORs associated with oral and transdermal } \\
\text { MHT are heterogeneous for fatal events }\end{array}$} \\
\hline & & \multirow{3}{*}{$\begin{array}{l}198 \text { women with fatal } \\
\text { myocardial infarction and } 393 \\
\text { controls }\end{array}$} & ORs of fatal events for ever-use versus MHT never-use: & \\
\hline & & & Oral MHT: 0.40 (0.26-0.63; 29 cases $)$ & \\
\hline & & & Transdermal MHT: 1.31 (0.47-3.68; seven cases) & \\
\hline \multirow{3}{*}{$\begin{array}{l}\text { Hippisley-Cox } \\
(2003)^{22}\end{array}$} & \multirow[t]{3}{*}{ United Kingdom, no age limit } & \multirow{2}{*}{$\begin{array}{l}\text { Population-based case-control } \\
\text { study using practice computer } \\
\text { records }\end{array}$} & ORs for current use versus MHT never-use: & \multirow[t]{3}{*}{ ORs are multivariable-adjusted } \\
\hline & & & Oral MHT: 1.27 (0.88-1.84; 50 cases) & \\
\hline & & $\begin{array}{l}417 \text { women with coronary heart } \\
\text { disease (angina, myocardial } \\
\text { infarction or coronary artery } \\
\text { surgery) and } 2435 \text { controls }\end{array}$ & Transdermal MHT: 1.61 (0.76-3.39; 10 cases) & \\
\hline \multirow[t]{3}{*}{ De Vries $(2006)^{18}$} & \multirow{3}{*}{$\begin{array}{l}\text { United Kingdom, } \\
\text { peri/postmenopausal women } \\
\text { aged } 40-74 \text { years }\end{array}$} & \multirow{3}{*}{$\begin{array}{l}\text { Population-based case-control } \\
\text { study using the General } \\
\text { Practice Research Database } \\
4537 \text { women with myocardial } \\
\text { infarction and } 27,220 \text { controls }\end{array}$} & ORs for current use versus MHT never-use: & ORs are multivariable-adjusted \\
\hline & & & Oral MHT: 0.77 (0.66-0.90; 268 cases $)$ & \multirow{2}{*}{$\begin{array}{l}P \text { for homogeneity between oral and } \\
\text { transdermal MHT: } 0.25\end{array}$} \\
\hline & & & Transdermal MHT: 0.66 (0.49-0.88; 62 cases) & \\
\hline \multirow[t]{3}{*}{ Corrao $(2007)^{20}$} & \multirow{3}{*}{$\begin{array}{l}\text { Italy, women aged } 45-65 \text { years } \\
\text { who received at least one MHT } \\
\text { prescription during } 1998-2000\end{array}$} & Record-linkage cohort study & HRs for use $>3$ years versus $<7$ months: & \multirow[t]{3}{*}{ HRs are multivariable-adjusted } \\
\hline & & 76,875 women of whom 473 & Oral MHT: $1.80(0.66-4.88)$ & \\
\hline & & $\begin{array}{l}\text { experienced hospitalization for } \\
\text { ischaemic heart disease }\end{array}$ & Transdermal MHT: 0.59 (0.33-1.05) & \\
\hline \multirow{5}{*}{$\begin{array}{l}\text { Løkkegaard } \\
(2008)^{21}\end{array}$} & \multirow{5}{*}{$\begin{array}{l}\text { Denmark, healthy women aged } \\
51-69 \text { years }\end{array}$} & Record-linkage cohort study & HRs for current use versus MHT never-use: & HRs are multivariable-adjusted \\
\hline & & \multirow{4}{*}{$\begin{array}{l}698,098 \text { women of whom } 4947 \\
\text { experienced a myocardial } \\
\text { infarction }\end{array}$} & Oral E-MHT: 0.98 (0.67-1.12; 264 cases) & \multirow{2}{*}{$\begin{array}{l}P \text { for homogeneity between oral and } \\
\text { transdermal E-MHT: } 0.04\end{array}$} \\
\hline & & & Transdermal E-MHT: 0.62 (0.42-0.93; 24 cases) & \\
\hline & & & Oral EP-MHT: 1.08 (0.98-1.19; 523 cases) & \multirow{2}{*}{$\begin{array}{l}P \text { for homogeneity between oral and } \\
\text { transdermal EP-MHT: } 0.33\end{array}$} \\
\hline & & & Transdermal EP-MHT: 0.95 (0.63-1.43; 23 cases) & \\
\hline
\end{tabular}


$\mathrm{Cl}$, confidence interval; E-MHT, estrogen-alone therapy; EP-MHT, estrogen-progestagen therapy; HR, hazard-ratio; MHT, menopausal hormone therapy (estrogen-alone or estrogen-progestagen therapy); OR, odds-ratio 
Table 2. Risk of venous thromboembolism - Results of observational studies comparing oral and transdermal MHT

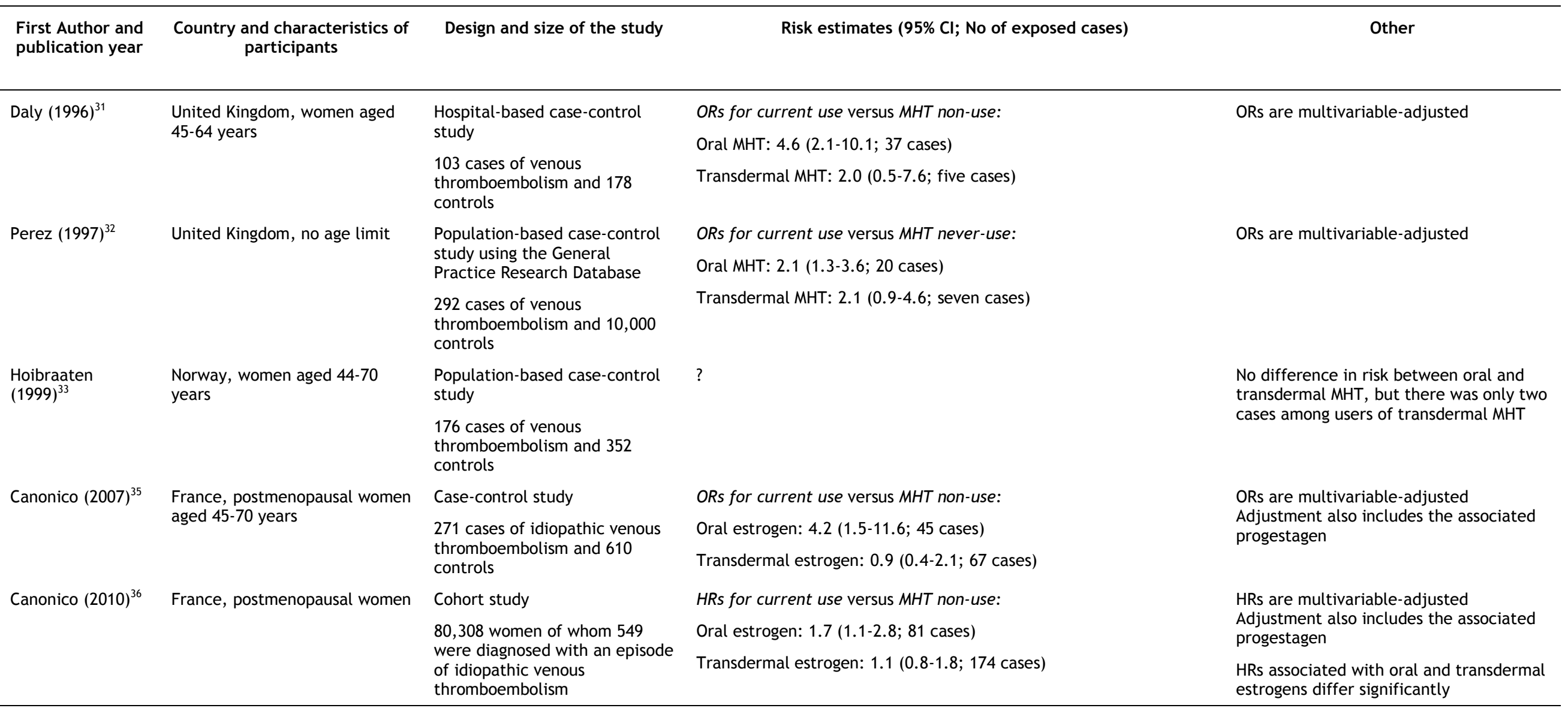

$\mathrm{Cl}$, confidence interval; E-MHT, estrogen-alone therapy; EP-MHT, estrogen-progestagen therapy; HR, hazard-ratio; MHT, menopausal hormone therapy (estrogen-alone or estrogen-progestagen therapy); OR, odds-ratio 
Table 3. Risk of breast cancer - Results of observational studies comparing oral and transdermal MHT

\begin{tabular}{|c|c|c|c|c|}
\hline $\begin{array}{l}\text { First Author and } \\
\text { publication year }\end{array}$ & $\begin{array}{l}\text { Country and characteristics of } \\
\text { participants }\end{array}$ & Design and size of the study & Risk estimates ( $95 \% \mathrm{Cl}$; No of exposed cases) & Other \\
\hline \multirow[t]{3}{*}{ Beral $(2003)^{3}$} & \multirow{3}{*}{$\begin{array}{l}\text { United Kingdom, women aged } \\
50-64 \text { years }\end{array}$} & Cohort study & HRs for current use versus $M H T$ never-use: & HRs are multivariable-adjusted \\
\hline & & \multirow{2}{*}{$\begin{array}{l}1,084,110 \text { women of whom } \\
9364 \text { were diagnosed with } \\
\text { invasive breast cancer }\end{array}$} & Oral E-MHT: 1.32 (1.21-1.45; 606 cases) & \multirow{2}{*}{$\begin{array}{l}\text { No significant difference between HRs } \\
\text { associated with oral and transdermal E- } \\
\text { MHT }\end{array}$} \\
\hline & & & Transdermal E-MHT: 1.24 (1.11-1.39; 324 cases) & \\
\hline \multirow[t]{7}{*}{ Lyytinen $(2006)^{43}$} & \multirow{7}{*}{$\begin{array}{l}\text { Finland, women older than age } \\
50 \text { years who had bought E-MHT } \\
\text { for at least } 6 \text { months during } \\
1994-2001\end{array}$} & \multirow{7}{*}{$\begin{array}{l}\text { Cohort record-linkage study } \\
110,984 \text { women of whom } 2171 \\
\text { were diagnosed with breast } \\
\text { cancer }\end{array}$} & SIRs with the entire age-matched women Finnish population as the & \multirow{7}{*}{$\begin{array}{l}\text { The breast cancer incidence in the cohort } \\
\text { was compared to that among the entire } \\
\text { age-matched women Finnish population } \\
\text { using SIR }\end{array}$} \\
\hline & & & Low-dose oral E-MHT $\geq 5$ years: $1.15(0.71-1.75 ; 21$ cases $)$ & \\
\hline & & & Low-dose transdermal E-MHT $\geq 5$ years: $1.60(0.77-2.95 ; 10$ cases $)$ & \\
\hline & & & Medium-dose oral E-MHT $\geq 5$ years: $1.38(0.84-2.12 ; 20$ cases $)$ & \\
\hline & & & $\begin{array}{l}\text { Medium-dose transdermal E-MHT } \geq 5 \text { years: } 1.32(1.12-1.64 ; 104 \\
\text { cases) }\end{array}$ & \\
\hline & & & High-dose oral E-MHT $\geq 5$ years: 1.49 (1.25-1.75; 130 cases $)$ & \\
\hline & & & High-dose transdermal E-MHT $\geq 5$ years: 1.44 (0.88-2.22; 20 cases) & \\
\hline \multirow[t]{7}{*}{ Lyytinen $(2009)^{44}$} & \multirow{7}{*}{$\begin{array}{l}\text { Finland, women older than age } \\
50 \text { years who had bought EP- } \\
\text { MHT for at least } 6 \text { months in } \\
1994-2005\end{array}$} & \multirow{7}{*}{$\begin{array}{l}\text { Cohort record-linkage study } \\
221,551 \text { women of whom } 6211 \\
\text { were diagnosed with breast } \\
\text { cancer }\end{array}$} & $\begin{array}{l}\text { SIRs with the entire age-matched women Finnish population as the } \\
\text { reference. }\end{array}$ & \multirow{7}{*}{$\begin{array}{l}\text { The breast cancer incidence in the cohort } \\
\text { was compared to that among the entire } \\
\text { age-matched women Finnish population } \\
\text { using SIR }\end{array}$} \\
\hline & & & & \\
\hline & & & Transdermal EP-MHT 0.5 to <3years: $0.99(0.79-1.23,82$ cases $)$ & \\
\hline & & & Oral EP-MHT 3 to <5years: $1.27(1.15-1.39,440$ cases $)$ & \\
\hline & & & Transdermal EP-MHT 3 to <5years: $1.38(1.01-1.85,45$ cases $)$ & \\
\hline & & & 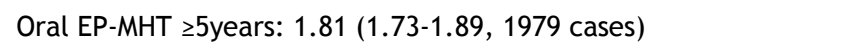 & \\
\hline & & & Transdermal EP-MHT $\geq 5$ years: 1.60 (1.11-2.23, 34 cases $)$ & \\
\hline \multirow[t]{3}{*}{ Opatrny $(2008)^{48}$} & \multirow{3}{*}{$\begin{array}{l}\text { United Kingdom, women aged } \\
50-75 \text { years }\end{array}$} & \multirow{2}{*}{$\begin{array}{l}\text { Population-based case-control } \\
\text { study using the General } \\
\text { Practice Research Database }\end{array}$} & ORs for ever-use versus MHT never-use: & \multirow[t]{3}{*}{ ORs are multivariable-adjusted } \\
\hline & & & Oral EP-MHT: 1.38 (1.27-1.48; 1120 cases $)$ & \\
\hline & & $\begin{array}{l}6347 \text { women diagnosed with } \\
\text { breast cancer and } 31,516 \\
\text { controls }\end{array}$ & Transdermal EP-MHT: 1.08 (0.81-1.43; 60 cases $)$ & \\
\hline \multirow[t]{3}{*}{ Corrao $(2008)^{49}$} & \multirow{3}{*}{$\begin{array}{l}\text { Italy, women aged } 45-75 \text { years } \\
\text { who received at least one MHT } \\
\text { prescription during } 1998-2000\end{array}$} & Record-linkage cohort study & HRs for use $>2$ years versus $<6$ months: & HRs are age-adjusted \\
\hline & & \multirow{2}{*}{$\begin{array}{l}73,505 \text { women of whom } 1296 \\
\text { experienced hospitalization for } \\
\text { breast cancer }\end{array}$} & Oral MHT: 2.14 (1.43-3.21) & \multirow{2}{*}{$\begin{array}{l}P \text { for homogeneity between oral and } \\
\text { transdermal MHT: } 0.01\end{array}$} \\
\hline & & & Transdermal MHT: 1.27 (1.07-1.51) & \\
\hline \multirow[t]{2}{*}{ Fournier $(2005)^{46}$} & \multirow[t]{2}{*}{ France, postmenopausal women } & Cohort study & HRs for ever-use versus MHT never-use: & HRs are multivariable-adjusted \\
\hline & & 54,548 women of whom 948 & Oral EP-MHT: 1.5 (1.1-1.9; 80 cases $)$ & EP-MHT excludes MHT containing \\
\hline
\end{tabular}


were diagnosed with breast cancer

Transdermal EP-MHT: 1.4 (1.2-1.7; 187 cases)

Fournier (2008) $)^{47}$

France, postmenopausal women Cohort study

80,377 women of whom 2354 were diagnosed with breast cancer

HRs for ever-use versus MHT never-use:

Oral E-MHT: 1.32 (0.76-2.29; 13 cases)

Transdermal E-MHT: 1.28 (0.98-1.69; 56 cases)

Oral estrogen+dydrogesterone: 0.77 (0.36-1.62; 7 cases)

Transdermal estrogen+dydrogesterone: 1.18 (0.95-1.48; 90 cases)

Oral estrogen+medrogestone: 2.74 (1.42-5.29; 9 cases)

Transdermal estrogen+medrogestone: 2.03 (1.39-2.97; 28 cases)

Oral estrogen+chlormadinone acetate: 2.02 (1.00-4.06; 8 cases)

Transdermal estrogen+chlormadinone acetate: 1.48 (1.05-2.09; 35 cases)

Oral estrogen+promegestone: 1.62 (0.94-2.82; 13 cases)

Transdermal estrogen+promegestone: 1.52 (1.19-1.96; 69 cases)

Oral estrogen+nomegestrol acetate: 1.10 (0.55-2.21; 8 cases)

Transdermal estrogen+nomegestrol acetate: 1.60 (1.28-2.01; 91 cases)

$\mathrm{Cl}$, confidence interval; E-MHT, estrogen-alone therapy; EP-MHT, estrogen-progestagen therapy; HR, hazard-ratio; MHT, menopausal hormone therapy (estrogen-alone or estrogen-progestagen therapy); OR, odds-ratio; SIR, standardized incidence ratio 
Table 4. Risk of colorectal cancer - Results of observational studies comparing oral and transdermal MHT

\begin{tabular}{|c|c|c|c|c|}
\hline $\begin{array}{l}\text { First Author and } \\
\text { publication year }\end{array}$ & $\begin{array}{c}\text { Country and characteristics } \\
\text { of participants }\end{array}$ & Design and size of the study & Risk estimates ( $95 \% \mathrm{Cl}$; No of exposed cases) & Other \\
\hline \multirow[t]{3}{*}{ Csizmadi $(2004)^{66}$} & \multirow{3}{*}{$\begin{array}{l}\text { Canada, women } 50 \text { years of } \\
\text { age or older }\end{array}$} & \multirow{2}{*}{$\begin{array}{l}\text { Population-based nested case- } \\
\text { control study using record- } \\
\text { linkage data }\end{array}$} & ORs for ever-use versus MHT never-use: & ORs are age-adjusted \\
\hline & & & Oral MHT: 0.82 (0.70-0.97; 251 cases) & \multirow{2}{*}{$\begin{array}{l}\text { The difference between the estimates for } \\
\text { oral and transdermal MHT is statistically } \\
\text { significant when restricted to women } \\
\text { with exclusive use of one route of } \\
\text { administration ( } 230 \text { and five cases among } \\
\text { oral and transdermal MHT users, } \\
\text { respectively) }\end{array}$} \\
\hline & & $\begin{array}{l}1197 \text { cases of colorectal cancer } \\
\text { and } 4669 \text { age-matched controls }\end{array}$ & Transdermal MHT: 0.60 (0.39-0.92; 26 cases) & \\
\hline \multirow[t]{3}{*}{ Dinger $(2007)^{68}$} & \multirow[t]{3}{*}{ Germany, no age limit } & Case-control study & ORs for ever-use versus MHT never-use: & \multirow[t]{3}{*}{ ORs are multivariable-adjusted } \\
\hline & & \multirow{2}{*}{$\begin{array}{l}354 \text { cases of colon cancer and } \\
1422 \text { age-matched controls }\end{array}$} & Oral MHT: 0.76 (0.54-1.08; 99 cases) & \\
\hline & & & Transdermal MHT: 1.17 (0.63-2.16; 24 cases) & \\
\hline \multirow[t]{3}{*}{ Corrao $(2008)^{49}$} & \multirow{3}{*}{$\begin{array}{l}\text { Italy, women aged } 45-75 \\
\text { years who received at least } \\
\text { one MHT prescription during } \\
\text { 1998-2000 }\end{array}$} & Record-linkage cohort study & $H R s$ for use $>2$ years versus $<6$ months: & HRs are age-adjusted \\
\hline & & \multirow{2}{*}{$\begin{array}{l}73,505 \text { women of whom } 383 \\
\text { experienced hospitalization for } \\
\text { colorectal cancer }\end{array}$} & Oral MHT: 0.55 (0.13-2.21) & \multirow{2}{*}{$\begin{array}{l}P \text { for homogeneity between oral and } \\
\text { transdermal MHT: } 0.45\end{array}$} \\
\hline & & & Transdermal MHT: 0.81 (0.57-1.15) & \\
\hline \multirow[t]{3}{*}{ Rennert $(2009)^{60}$} & \multirow{3}{*}{$\begin{array}{l}\text { Israel, peri/postmenopausal } \\
\text { women }\end{array}$} & \multirow{2}{*}{$\begin{array}{l}\text { Population-based case-control } \\
\text { study }\end{array}$} & ORs for ever-use versus MHT never-use: & \multirow[t]{3}{*}{ ORs are age-adjusted } \\
\hline & & & Oral MHT: 0.68 (0.52-0.90) & \\
\hline & & $\begin{array}{l}1234 \text { cases of colorectal cancer } \\
\text { and } 1226 \text { age-matched controls }\end{array}$ & Transdermal MHT: $1.00(0.46-2.18)$ & \\
\hline \multirow[t]{5}{*}{ Hoffmeister $(2009)^{67}$} & \multirow{5}{*}{$\begin{array}{l}\text { Germany, postmenopausal } \\
\text { women }\end{array}$} & \multirow{2}{*}{$\begin{array}{l}\text { Population-based case-control } \\
\text { study }\end{array}$} & ORs for ever-use versus MHT never-use: & ORs are multivariable-adjusted \\
\hline & & & Oral MHT: 0.59 (0.39-0.90; 56 cases) & \multirow{4}{*}{$\begin{array}{l}P \text { for homogeneity between oral and } \\
\text { transdermal MHT: } 0.37\end{array}$} \\
\hline & & \multirow{3}{*}{$\begin{array}{l}546 \text { colorectal cancer cases and } \\
910 \text { controls }\end{array}$} & Transdermal MHT: 0.40 (0.17-0.90; nine cases) & \\
\hline & & & Oral E-MHT: 0.44 (0.15-1.30; six cases) & \\
\hline & & & Transdermal E-MHT: 0.36 (0.14-0.97; six cases) & \\
\hline
\end{tabular}

$\mathrm{Cl}$, confidence interval; E-MHT, estrogen-alone therapy; EP-MHT, estrogen-progestagen therapy; HR, hazard-ratio; MHT, menopausal hormone therapy (estrogen-alone or estrogen-progestagen therapy); OR, odds-ratio 


\section{References}

1. Rossouw JE, Anderson GL, Prentice RL et al. Risks and benefits of estrogen plus progestin in healthy postmenopausal women: principal results From the Women's Health Initiative randomized controlled trial. JAMA 2002;288:321-33.

2. Chlebowski RT, Hendrix SL, Langer RD et al. Influence of estrogen plus progestin on breast cancer and mammography in healthy postmenopausal women: the Women's Health Initiative Randomized Trial. JAMA 2003;289:3243-53.

3. Beral V. Breast cancer and hormone-replacement therapy in the Million Women Study. Lancet 2003;362:419-27.

4. The European Agency for the Evaluation of Medicinal Products. EMEA public statement on recent publications regarding hormone replacement therapy; December 3, 2003. See http://www.emea.europa.eu/pdfs/human/press/pus/3306503en.pdf). Accessed march 19, 2010.

5. World Health Organization. The global burden of disease: 2004 update. Geneva, World Health Organization, 2008. See http://www.who.int/evidence/bod. Accessed march 19, 2010.

6. Johnell 0 , Kanis JA. An estimate of the worldwide prevalence, mortality and disability associated with hip fracture. Osteoporos Int 2004;15:897-902.

7. Barrett-Connor E. Hormone replacement therapy. BMJ 1998;317:457-61.

8. Hulley S, Grady D, Bush T et al. Randomized trial of estrogen plus progestin for secondary prevention of coronary heart disease in postmenopausal women. Heart and Estrogen/progestin Replacement Study (HERS) Research Group. JAMA 1998;280:605-13.

9. Grady D, Herrington D, Bittner V et al. Cardiovascular disease outcomes during 6.8 years of hormone therapy: Heart and Estrogen/progestin Replacement Study follow-up (HERS II). JAMA 2002;288:49-57.

10. Manson JE, Hsia J, Johnson $\mathrm{KC}$ et al. Estrogen plus progestin and the risk of coronary heart disease. N Engl J Med 2003;349:523-34.

11. Hsia J, Langer RD, Manson JE et al. Conjugated equine estrogens and coronary heart disease: the Women's Health Initiative. Arch Intern Med 2006;166:357-65.

12. Grodstein F, Clarkson TB, Manson JE. Understanding the divergent data on postmenopausal hormone therapy. N Engl J Med 2003;348:645-50.

13. Ray WA. Evaluating medication effects outside of clinical trials: new-user designs. Am J Epidemiol 2003;158:915-20.

14. Phillips LS, Langer RD. Postmenopausal hormone therapy: critical reappraisal and a unified hypothesis. Fertil Steril 2005;83:558-66. 
15. Banks E, Canfell K. Invited Commentary: Hormone therapy risks and benefits--The Women's Health Initiative findings and the postmenopausal estrogen timing hypothesis. Am J Epidemiol 2009;170:24-28.

16. Sare GM, Gray LJ, Bath PM. Association between hormone replacement therapy and subsequent arterial and venous vascular events: a meta-analysis. Eur Heart J 2008;29:2031-41.

17. Varas-Lorenzo C, Garcia-Rodriguez LA, Perez-Gutthann S, Duque-Oliart A. Hormone replacement therapy and incidence of acute myocardial infarction. A populationbased nested case-control study. Circulation 2000;101:2572-78.

18. de Vries CS, Bromley SE, Farmer RD. Myocardial infarction risk and hormone replacement: differences between products. Maturitas 2006;53:343-50.

19. Chilvers CE, Knibb RC, Armstrong SJ, Woods KL, Logan RF. Post menopausal hormone replacement therapy and risk of acute myocardial infarction--a case control study of women in the East Midlands, UK. Eur Heart J 2003;24:2197-205.

20. Corrao G, Zambon A, Nicotra F et al. Persistence with oral and transdermal hormone replacement therapy and hospitalisation for cardiovascular outcomes. Maturitas 2007;57:315-24.

21. Lokkegaard E, Andreasen AH, Jacobsen RK, Nielsen LH, Agger C, Lidegaard O. Hormone therapy and risk of myocardial infarction: a national register study. Eur Heart J 2008;29:2660-2668.

22. Hippisley-Cox J, Pringle M, Crown N, Coupland C. A case-control study on the effect of hormone replacement therapy on ischaemic heart disease. Br J Gen Pract 2003;53:191-96.

23. Bath PM, Gray LJ. Association between hormone replacement therapy and subsequent stroke: a meta-analysis. BMJ 2005;330:342.

24. Nelson HD, Humphrey LL, Nygren P, Teutsch SM, Allan JD. Postmenopausal hormone replacement therapy: scientific review. JAMA 2002;288:872-81.

25. Arana A, Varas C, Gonzalez-Perez A, Gutierrez L, Bjerrum L, Garcia Rodriguez LA. Hormone therapy and cerebrovascular events: a population-based nested casecontrol study. Menopause 2006;13:730-736.

26. Grodstein F, Manson JE, Stampfer MJ, Rexrode K. Postmenopausal hormone therapy and stroke: role of time since menopause and age at initiation of hormone therapy. Arch Intern Med 2008;168:861-66.

27. Renoux C, Dell'Aniello S, Garbe E, Suissa S. Hormone replacement therapy use and the risk of stroke. Maturitas 2008;61:305-9.

28. Prentice RL, Langer R, Stefanick ML et al. Combined postmenopausal hormone therapy and cardiovascular disease: toward resolving the discrepancy between observational studies and the Women's Health Initiative clinical trial. Am J Epidemiol 2005;162:404-14. 
29. Lemaitre RN, Weiss NS, Smith NL et al. Esterified estrogen and conjugated equine estrogen and the risk of incident myocardial infarction and stroke. Arch Intern Med 2006;166:399-404.

30. Canonico M, Plu-Bureau G, Lowe GD, Scarabin PY. Hormone replacement therapy and risk of venous thromboembolism in postmenopausal women: systematic review and meta-analysis. BMJ 2008;336:1227-31.

31. Daly E, Vessey MP, Hawkins MM, Carson JL, Gough P, Marsh S. Risk of venous thromboembolism in users of hormone replacement therapy. Lancet 1996;348:97780.

32. Perez GS, Garcia Rodriguez LA, Castellsague J, Duque OA. Hormone replacement therapy and risk of venous thromboembolism: population based case-control study. BMJ 1997;314:796-800.

33. Hoibraaten E, Abdelnoor M, Sandset PM. Hormone replacement therapy with estradiol and risk of venous thromboembolism--a population-based case-control study. Thromb Haemost 1999;82:1218-21.

34. Varas-Lorenzo C, Garcia-Rodriguez LA, Cattaruzzi C, Troncon MG, Agostinis L, Perez-Gutthann S. Hormone replacement therapy and the risk of hospitalization for venous thromboembolism: a population-based study in southern Europe. Am J Epidemiol 1998;147:387-90.

35. Canonico M, Oger E, Plu-Bureau et al. Hormone therapy and venous thromboembolism among postmenopausal women: impact of the route of estrogen administration and progestogens: the ESTHER study. Circulation 2007;115:840-845.

36. Canonico M, Fournier A, Carcaillon L et al. Postmenopausal hormone therapy and risk of idiopathic venous thromboembolism: results from the E3N cohort study. Arterioscler Thromb Vasc Biol 2010;30:340-345.

37. Cogliano V, Grosse Y, Baan R, Straif K, Secretan B, El Ghissassi F. Carcinogenicity of combined oestrogen-progestagen contraceptives and menopausal treatment. Lancet Oncol 2005;6:552-53.

38. Shah NR, Borenstein J, Dubois RW. Postmenopausal hormone therapy and breast cancer: a systematic review and meta-analysis. Menopause 2005;12:668-78.

39. Collins JA, Blake JM, Crosignani PG. Breast cancer risk with postmenopausal hormonal treatment. Hum Reprod Update 2005;11:545-60.

40. Chlebowski RT, Kuller LH, Prentice RL et al. Breast cancer after use of estrogen plus progestin in postmenopausal women. N Engl J Med 2009;360:573-87.

41. Ringa $V$, Fournier $A$. [Did the decrease in use of menopausal hormone therapy induce a decrease in the incidence of breast cancer in France (and elsewhere)?]. Rev Epidemiol Sante Publique 2008;56:297-301. 
42. Stefanick ML, Anderson GL, Margolis KL et al. Effects of conjugated equine estrogens on breast cancer and mammography screening in postmenopausal women with hysterectomy. JAMA 2006;295:1647-57.

43. Lyytinen $\mathrm{H}$, Pukkala E, Ylikorkala O. Breast cancer risk in postmenopausal women using estrogen-only therapy. Obstet Gynecol 2006;108:1354-60.

44. Lyytinen $\mathrm{H}$, Pukkala E, Ylikorkala O. Breast cancer risk in postmenopausal women using estradiol-progestogen therapy. Obstet Gynecol 2009;113:65-73.

45. Lyytinen, H., Dyba, T., Pukkala, E., and Ylikorkala, O. Do the dose or route of administration of norethisterone acetate as part of hormone therapy play a role in risk of breast cancer: Nation-wide case-control study from Finland. Int.J.Cancer. 2010.

46. Fournier A, Berrino F, Riboli E, Avenel V, Clavel-Chapelon F. Breast cancer risk in relation to different types of hormone replacement therapy in the E3N-EPIC cohort. Int J Cancer 2005;114:448-54.

47. Fournier A, Berrino F, Clavel-Chapelon F. Unequal risks for breast cancer associated with different hormone replacement therapies: results from the E3N cohort study. Breast Cancer Res Treat 2008;107:103-11.

48. Opatrny L, Dell'Aniello S, Assouline S, Suissa S. Hormone replacement therapy use and variations in the risk of breast cancer. BJOG 2008;115:169-75.

49. Corrao G, Zambon A, Conti V et al. Menopause hormone replacement therapy and cancer risk: an Italian record linkage investigation. Ann Oncol 2008;19:150-155.

50. Lee SA, Ross RK, Pike MC. An overview of menopausal oestrogen-progestin hormone therapy and breast cancer risk. Br J Cancer 2005;92:2049-58.

51. Salpeter SR, Walsh JM, Ormiston TM, Greyber E, Buckley NS, Salpeter EE. Metaanalysis: effect of hormone-replacement therapy on components of the metabolic syndrome in postmenopausal women. Diabetes Obes Metab 2006;8:538-54.

52. Manson JE, Rimm EB, Colditz GA et al. A prospective study of postmenopausal estrogen therapy and subsequent incidence of non-insulin-dependent diabetes mellitus. Ann Epidemiol 1992;2:665-73.

53. Lauzon-Guillain B, Fournier A, Fabre A et al. Menopausal hormone therapy and new-onset diabetes in the French Etude Epidemiologique de Femmes de la Mutuelle Generale de l'Education Nationale (E3N) cohort. Diabetologia 2009;52:2092-100.

54. Gabal LL, Goodman-Gruen D, Barrett-Connor E. The effect of postmenopausal estrogen therapy on the risk of non-insulin-dependent diabetes mellitus. Am J Public Health 1997;87:443-45. 
55. Zhang Y, Howard BV, Cowan LD et al. The effect of estrogen use on levels of glucose and insulin and the risk of type 2 diabetes in american Indian postmenopausal women : the strong heart study. Diabetes Care 2002;25:500-504.

56. Rossi R, Origliani G, Modena MG. Transdermal 17-beta-estradiol and risk of developing type 2 diabetes in a population of healthy, nonobese postmenopausal women. Diabetes Care 2004;27:645-49.

57. Grodstein F, Newcomb PA, Stampfer MJ. Postmenopausal hormone therapy and the risk of colorectal cancer: a review and meta-analysis. Am J Med 1999;106:574-82.

58. Campbell PT, Newcomb P, Gallinger S, Cotterchio M, McLaughlin JR. Exogenous hormones and colorectal cancer risk in Canada: associations stratified by clinically defined familial risk of cancer. Cancer Causes Control 2007;18:723-33.

59. Johnson JR, Lacey JV, Jr., Lazovich D et al. Menopausal hormone therapy and risk of colorectal cancer. Cancer Epidemiol Biomarkers Prev 2009;18:196-203.

60. Rennert G, Rennert HS, Pinchev M, Lavie O, Gruber SB. Use of hormone replacement therapy and the risk of colorectal cancer. J Clin Oncol 2009;27:454247.

61. Newcomb PA, Zheng Y, Chia VM et al. Estrogen plus progestin use, microsatellite instability, and the risk of colorectal cancer in women. Cancer Res 2007;67:753439.

62. Hildebrand JS, Jacobs EJ, Campbell PT et al. Colorectal cancer incidence and postmenopausal hormone use by type, recency, and duration in cancer prevention study II. Cancer Epidemiol Biomarkers Prev 2009;18:2835-41.

63. Kabat GC, Miller AB, Rohan TE. Oral contraceptive use, hormone replacement therapy, reproductive history and risk of colorectal cancer in women. Int J Cancer 2008;122:643-46.

64. Ritenbaugh C, Stanford JL, Wu L et al. Conjugated equine estrogens and colorectal cancer incidence and survival: the Women's Health Initiative randomized clinical trial. Cancer Epidemiol Biomarkers Prev 2008;17:2609-18.

65. Chlebowski RT, Wactawski-Wende J, Ritenbaugh C et al. Estrogen plus progestin and colorectal cancer in postmenopausal women. N Engl J Med 2004;350:991-1004.

66. Csizmadi I, Collet JP, Benedetti A, Boivin JF, Hanley JA. The effects of transdermal and oral oestrogen replacement therapy on colorectal cancer risk in postmenopausal women. Br J Cancer 2004;90:76-81.

67. Hoffmeister M, Raum E, Krtschil A, Chang-Claude J, Brenner H. No evidence for variation in colorectal cancer risk associated with different types of postmenopausal hormone therapy. Clin Pharmacol Ther 2009;86:416-24.

68. Dinger JC, Heinemann LA, Mohner S, Thai dM, Assmann A. Colon cancer risk and different HRT formulations: a case-control study. BMC Cancer 2007;7:76. 
69. Cauley JA, Robbins J, Chen Z et al. Effects of estrogen plus progestin on risk of fracture and bone mineral density: the Women's Health Initiative randomized trial. JAMA 2003;290:1729-38.

70. Jackson RD, Wactawski-Wende J, LaCroix AZ et al. Effects of conjugated equine estrogen on risk of fractures and BMD in postmenopausal women with hysterectomy: results from the women's health initiative randomized trial. J Bone Miner Res 2006;21:817-28.

71. Hulley S, Furberg C, Barrett-Connor E et al. Noncardiovascular disease outcomes during 6.8 years of hormone therapy: Heart and Estrogen/progestin Replacement Study follow-up (HERS II). JAMA 2002;288:58-66.

72. Torgerson DJ, Bell-Syer SE. Hormone replacement therapy and prevention of nonvertebral fractures: a meta-analysis of randomized trials. JAMA 2001;285:289197.

73. Banks E, Beral V, Reeves G, Balkwill A, Barnes I. Fracture incidence in relation to the pattern of use of hormone therapy in postmenopausal women. JAMA 2004;291:2212-20.

74. Vestergaard P, Rejnmark L, Mosekilde L. Fracture reducing potential of hormone replacement therapy on a population level. Maturitas 2006;54:285-93.

75. Weiner MG, Barnhart K, Xie D, Tannen RL. Hormone therapy and coronary heart disease in young women. Menopause 2008;15:86-93.

76. Michaelsson K, Baron JA, Farahmand BY et al. Hormone replacement therapy and risk of hip fracture: population based case-control study. The Swedish Hip Fracture Study Group. BMJ 1998;316:1858-63. 